\title{
A comprehensive study of the high temperature pyrolysis of sewage sludge: kinetics, energy analysis and products formation
}

\author{
Mendoza-Geney L.*, Rincón Prat S. and Gómez A. \\ Universidad Nacional de Colombia - sede Bogotá - Facultad de Ingeniería - Departamento de Ingeniería Mecánica y Mecatrónica - \\ Grupo de Investigación en Biomasa y Optimización Térmica de Procesos - Carrera 30 No $45 \mathrm{~A}-03$ Edificio 453 Of. 400 , Bogotá, Colombia \\ Received: 20/05/2021, Accepted: 18/12/2021, Available online: 23/12/2021 \\ *to whom all correspondence should be addressed: e-mail: lemendozag@unal.edu.co \\ https://doi.org/10.30955/gnj.003738
}

\section{Graphical abstract}

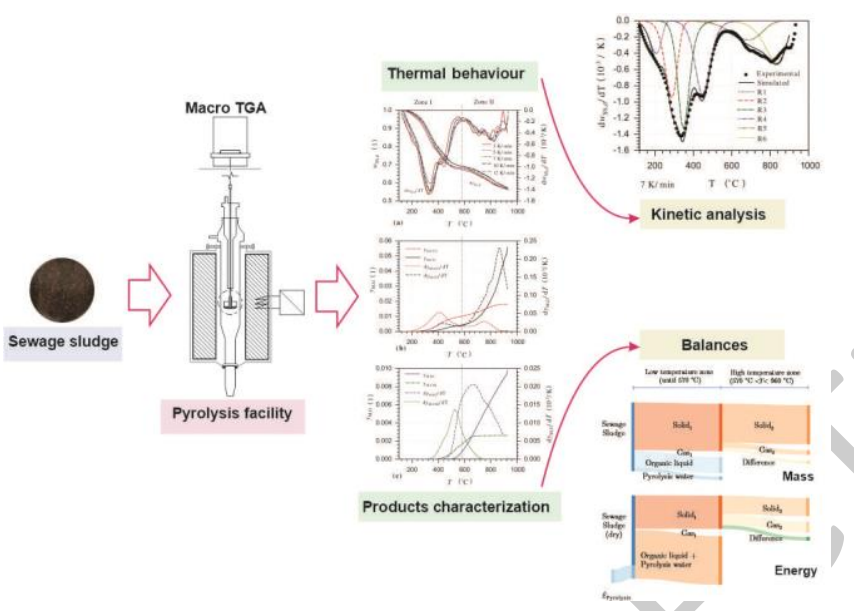

Abstract

This study evaluates the pyrolysis of sewage sludge until $960^{\circ} \mathrm{C}$ using heating rates between $3 \mathrm{~K} / \mathrm{min}$ and $12 \mathrm{~K} / \mathrm{min}$ in a macro TG/EGA. Mass and energy balances and kinetic parameters are determined. Thermal decomposition is divided into a low temperature zone (until $550^{\circ} \mathrm{C}$ to $590^{\circ} \mathrm{C}$ ), for decomposition of organic matter, and a high temperature zone, for decomposition of inorganic matter and secondary reactions of the residual organic matter. In dry basis at $570^{\circ} \mathrm{C}$ solid, liquid and gaseous products amount to $69.2 \mathrm{wt} \%, 29.2 \mathrm{wt} \%$ and $1.6 \mathrm{wt} \%$, respectively. An increment in the final temperature to $960^{\circ} \mathrm{C}$ causes a successive decrease of the solid residue to $56.9 \mathrm{wt} \%$. The solid product contains more than 80 wt\% mineral matter with high amounts of valuable elements, such as calcium (Ca) and phosphorus (P). An energy requirement of 2.18 $\mathrm{MJ} / \mathrm{kg}$ of dry sewage sludge is calculated for the pyrolysis until $570^{\circ} \mathrm{C}$. At this temperature, $58.5 \%$ of the energy entering the process is concentrated in the liquid product and $40.0 \%$ in the solid. A suitable set of kinetic parameters is determined through a formal independent parallel reactions model with six-pseudo components, using a combination of isoconversional and fitting methods.

Keywords: Pyrolysis, sewage sludge, thermogravimetry, kinetic modeling, mass and energy balances

\section{Introduction}

There are substantial benefits to be gained from thermochemical processing as an alternative route to sewage sludge disposal to landfill sites and soils. The composition of sewage sludge generated in wastewater treatment plants is complex and contains organic matter, pathogens, heavy metals, micropollutants and leachates (Kacprzak et al., 2017), but also relevant fractions of nutrients such as phosphorus, calcium, potassium and sodium (Chanaka et al., 2019b). Damages to the soil and water resources and risks to public health have led to increasing restrictions on the disposal of sewage sludge in landfills and soils worldwide (Kacprzak et al., 2017). However, the costs associated with its treatment through thermochemical processes, such as incineration, are higher than traditional disposal methods, which are still widely used. Due to the increasing deployment of wastewater treatment in developing countries and the tightening of wastewater regulations (Wichelns et al., 2015), an increase in global sewage sludge production is expected in the coming years. Moreover recent regulatory developments have encouraged the implementation of measures for the recovery of nutrients, especially phosphorus, present in sewage sludge (Bergfeldt et al., 2018).

The pyrolysis of sewage sludge has the potential to achieve advantages similar to those offered by incineration, such as the reduction in the volume of residues, the elimination of harmful components, the possibility of energy and nutrients recovery, and other uses to the inorganic solid residues (Kacprzak et al., 2017). The lower temperatures at which pyrolysis can be carried out, compared with incineration and gasification, offer operational advantages associated with the avoidance of heavy metals volatilization, dioxin and furans formation (Chanaka et al., 2019b), and other problems related to ash melting, sintering and agglomeration (Seggiani et al., 2012). The production of solid, liquid and gaseous products offers additional advantages for pyrolysis as a possible technical and ecological treatment of sewage sludge (Trinh et al., 2013). In relation to the use of char 
from sewage sludge pyrolysis, several studies have shown that the leaching potential of heavy metals decreases in charcoal (Chanaka et al., 2019b, Wesenbeeck et al., 2014). It has also been reported that the extraction potential of phosphorus $(P)$ for pyrolysis char is higher than that for combustion ash (Bergfeldt et al., 2018). Compared with lignocellulosic biomass, sewage sludge adds the complexity of its composition as a decisive variable during pyrolysis. Typically, after a dewatering step, it has a water content between 65 wt\% and 80 wt\% (Roskosch and Heidecke, 2018). For thermal processing, water contents below $15 \mathrm{wt} \%$ are desired, so an additional drying step must be added before processing (Gao et al., 2020). The dry matter of sewage sludge is composed of a fraction of organic matter that includes proteins, lipids, hemicellulose, cellulose and lignin (Thipkhunthod et al., 2007; Zhu et al., 2019), and by a fraction of inorganic matter, mainly silicates, oxides, sulphates and heavy metals Tang et al., 2018. This last fraction varies from around 20 wt\% to 54 wt\% (dry basis) (Thipkhunthod et al., 2007; Zhu et al., 2019) and exerts a determining influence on the yield of the solid residue due to catalytic effects and decomposition reactions at high temperatures Shao et al., 2010. The products distribution during sewage sludge pyrolysis is additionally influenced by the process parameters. Experimental pyrolysis studies are commonly performed until final temperatures between $450^{\circ} \mathrm{C}$ and $650^{\circ} \mathrm{C}$. Product yields, in dry basis, vary in a wide interval with solid mass fractions in the range between $32 \mathrm{wt} \%$ (Gao et al., 2014) and 78 wt\% (Trinh et al., 2013), liquid fractions between 14 wt\% (Trinh et al., 2013) and 48 wt\% (Álvarez et al., 2015), and gas fractions between 5 wt\% (Álvarez et al., 2015) and 40 wt\% (Karaca et al., 2018). Maximum liquid yields have been obtained between $500^{\circ} \mathrm{C}$ and $650^{\circ} \mathrm{C}$. The effects of the heating rate are appreciable until the end of the pyrolysis reactions of the organic fraction. With an increase in the pyrolysis temperature from $450^{\circ} \mathrm{C}$ to $650^{\circ} \mathrm{C}$ and $850^{\circ} \mathrm{C}$ (Gao et al., 2014; guanzo et al., 2002) reported very small variations in the product yields with the heating rate. (Casajus et al., 2009; Zhu et al., 2019) obtained similar solid yields at different heating rates when using final pyrolysis temperatures of $900^{\circ} \mathrm{C}$ and $1000^{\circ} \mathrm{C}$, respectively.

The high variability of sludge composition and its influence on pyrolysis also make it difficult to determine suitable reaction parameters for process development. Reaction kinetics has been mainly modeled using singlestep global (Ji et al., 2010), multiple-step (Casajus et al., 2009) and semi-global (Calvo et al., 1982; Calvo et al., 2004; Font et al., 2005; García et al., 2009; Thipkhunthod et al., 2007; Urban and Anta, 1982; Urych and Smolinski, 2016; Xu et al., 2018) reaction models. Semi-global models of independent parallel reactions, according to pseudo-components decomposition, represent satisfactorily the thermal decomposition of sewage sludge. Table 1 presents a summary of relevant kinetic studies for the pyrolysis of sewage sludge using this type of models. The determination of the kinetic parameters is performed mostly using fitting procedures applied to experimental data. Isoconversional methods are also applied in combination with a kinetic model. In these methods the activation energy is determined using experiments at different heating rates, thus avoiding the compensation effect between $E_{\mathrm{a}}$ and $k_{0}$ that can occur when applying only model-fitting (Anca et al., 2014). In the works presented in Table 1, Urban and Antal 2982 applied the Friedmann isoconversional method, while (Urych and Smolinski, 2016) use a combination of deconvolution of experimental data and application of the Kissinger-Akahira-Sunose (KAS) isoconversional method of each obtained curve.

The present work evaluates the pyrolysis of sewage sludge samples obtained from the wastewater treatment plant of Bogotá (Colombia). The aims of the study are to give a qualitative insight into the behavior of organic and inorganic matter during thermal decomposition of the sewage sludge, to establish mass and energy balances and to determine a suitable set of kinetic reaction parameters of the process. Pyrolysis temperatures up to $960^{\circ} \mathrm{C}$ are used. A macro TG-facility with evolved gas analysis (EGA) is employed. A formal kinetic model of six parallel independent reactions is used to represent the mass loss of sewage sludge samples during pyrolysis. Kinetic parameters are determined by combining isoconversional and fitting methods. The integral methods of Flynn-WallOzawa (FWO) and Kissinger-Akahira-Sunose (KAS) are used. The kinetic model is coupled with a stoichiometric reaction scheme to estimate the evolution of the solid, liquid and gas products. The suitability of the determined set of reaction parameters allows the simulation of the slow pyrolysis under different heating rates in the range between $100 \mathrm{~K} / \mathrm{min}$ and $200 \mathrm{~K} / \mathrm{min}$ and up to a high temperature of $960^{\circ} \mathrm{C}$. This model offers a tool for the scale-up of the process as part of a project under development, aiming at the production and evaluation of pyrolysis chars from sewage sludge.

\section{Materials and methods}

\subsection{Sewage sludge and products characterization}

Anaerobically digested sewage sludge samples were obtained from the wastewater treatment plant El Salitre, located in Bogotá - Colombia. A total of $50 \mathrm{~kg}$ of dewatered sludge were pre-dried and crushed to obtain a homogeneous particle size (smaller than $3 \mathrm{~mm}$ ). A sample of $1 \mathrm{~kg}$ was collected by quartering and submitted to a second drying step in a convection oven at $105^{\circ} \mathrm{C}$ during $10 \mathrm{~h}$. After milling and sieving, particle sizes between 0.18 $\mathrm{mm}$ and $0.25 \mathrm{~mm}$ were obtained. The samples were afterward characterized as indicated in Table 2. Elemental analysis and low heating value ( $L H V)$ of the solid product were determined using the standards indicated in the table. The ash content of the solid product was determined from a mass balance using the ash content of the sewage sludge sample determined at $960^{\circ} \mathrm{C}$. The $H H V$ of the organic liquid was calculated from its elemental composition using the experimental correlation of ( $\mathrm{Li}$ and Suzuki, 2010) presented in Eq. (1):

$$
H H V_{\mathrm{Ol}, \mathrm{d}}=34.09 c_{\mathrm{Ol}, \mathrm{d}}+132.2 h_{\mathrm{Ol}, \mathrm{d}}+11.99 o_{\mathrm{Ol}, \mathrm{d}}
$$


The low heating values $(L H V)$ were calculated from the high heating values using an evaporation enthalpy of 2.44
$\mathrm{MJ} / \mathrm{kg}$. LHV of the gas product was obtained from its composition according to ISO 6976:2016.

Table 1. Kinetic parameters reported for pyrolysis of sewage sludge from urban water using a scheme of independent parallel reactions, under operational conditions similar to those used in this work. In all works, an Arrhenius expression is used for the velocity constant. For the concentration function of the kinetic expression, a power law is applied.

\begin{tabular}{|c|c|c|c|c|c|c|c|c|}
\hline \multicolumn{2}{|c|}{ Country } & US & Spain & Spain & Thailand & Spain & Poland & China \\
\hline \multicolumn{2}{|c|}{ City } & Princeton & Leon & Alicante & Bangkok & Sevilla & Katowice & Shenzhen \\
\hline \multicolumn{2}{|c|}{ Heating rate $/ \mathrm{K} / \mathrm{min}$} & $1-50$ & 10 & $5-30$ & 20 & $5-10$ & $1-100$ & 10 \\
\hline \multicolumn{2}{|c|}{ Final temperature $/{ }^{\circ} \mathrm{C}$} & 600 & 650 & 550 & $600^{1}$ & 700 & 900 & 600 \\
\hline \multicolumn{9}{|c|}{ Decomposition of organic matter } \\
\hline \multirow{4}{*}{$\mathrm{R} 1^{6}$} & $E_{\mathrm{a}} / \mathrm{kJ} / \mathrm{mol}$ & 130 & 205 & 103.9 & 91.9 & 79.07 & - & 39.1 \\
\hline & $\ln k_{0} / 1 / \mathrm{s}$ & 41.45 & 40.4 & 20.12 & 25.7 & 12.14 & - & 2.13 \\
\hline & $n / 1$ & 10.0 & 2.4 & 4.13 & 1.03 & 0.96 & - & 1.94 \\
\hline & $y / 1$ & 0.32 & 0.05 & 0.26 & 0.16 & 0.26 & - & n.r. $^{2}$ \\
\hline \multirow{4}{*}{$\mathrm{R} 2$} & $E_{\mathrm{a}} / \mathrm{kJ} / \mathrm{mol}$ & 250.0 & 135.0 & 169.7 & 119.4 & 191.42 & 200.0 & 76.2 \\
\hline & $\ln k_{0} / 1 / \mathrm{s}$ & 57.56 & 21.99 & 28.98 & 29.7 & 33.59 & 37.35 & 11.33 \\
\hline & $n / 1$ & 15.0 & 1.7 & 4.06 & 1.53 & 2.96 & 1.0 & 4.41 \\
\hline & $y / 1$ & 0.68 & 0.49 & 0.57 & 0.15 & 0.32 & 0.41 & n.r. \\
\hline \multirow{4}{*}{ R3 } & $E_{\mathrm{a}} / \mathrm{kJ} / \mathrm{mol}$ & - & 138.0 & 209.4 & 76.4 & 80.72 & 179.0 & $2.2 \mathrm{e}-14$ \\
\hline & $\ln k_{0} / 1 / \mathrm{s}$ & - & 18.76 & 29.81 & 18.1 & 7.92 & 29.55 & -7.85 \\
\hline & $n / 1$ & - & 2.5 & 0.92 & 1.04 & 1.2 & 1.0 & 0.23 \\
\hline & $y / 1$ & - & 0.44 & 0.18 & 0.18 & 0.28 & 0.09 & n.r. \\
\hline \multirow{4}{*}{ R4 } & $E_{\mathrm{a}} / \mathrm{kJ} / \mathrm{mol}$ & - & - & - & 120.6 & 200.67 & 257.0 & - \\
\hline & $\ln k_{0} / 1 / \mathrm{s}$ & - & - & - & 22.8 & 20.48 & 39.92 & - \\
\hline & $n / 1$ & - & - & - & 0.92 & 0.59 & 1.0 & - \\
\hline & $y / 1$ & - & - & - & 0.41 & 0.1 & 0.22 & - \\
\hline \multicolumn{9}{|c|}{ Decomposition of inorganic matter } \\
\hline \multirow{4}{*}{ R5 } & $E_{\mathrm{a}} / \mathrm{kJ} / \mathrm{mol}$ & - & - & $2-2$ & - & 101.14 & 237.0 & - \\
\hline & $\ln k_{0} / 1 / \mathrm{s}$ & - & - & - & - & 22.23 & 25.02 & - \\
\hline & $n / 1$ & - & - & - & - & 2.95 & 1.0 & - \\
\hline & $y / 1$ & - & - & - & - & 0.04 & 0.04 & - \\
\hline \multirow{4}{*}{ R6 } & $E_{\mathrm{a}} / \mathrm{kJ} / \mathrm{mol}$ & - & - & - & - & - & 280.0 & - \\
\hline & $\ln k_{0} / 1 / \mathrm{s}$ & - & - & - & - & - & 26.58 & - \\
\hline & $n / 1$ & - & - & - & - & - & 1.0 & - \\
\hline & $y / 1$ & - & - & - & - & - & 0.06 & - \\
\hline Author & $\begin{array}{c}\text { Urban } \\
\text { and Antal }\end{array}$ & Calvo et al. & Font et al. & $\begin{array}{l}\text { Thipkhunthod } \\
\text { et al. }\end{array}$ & $\begin{array}{c}\text { García et } \\
\text { al. }\end{array}$ & $\begin{array}{l}\text { Urych and } \\
\text { Smolinski }\end{array}$ & Xu et al. & \\
\hline Year & $1982^{3}$ & 2004 & $2005^{3}$ & 2007 & $2009^{3}$ & $2016^{4,5}$ & 2018 & \\
\hline
\end{tabular}

${ }^{1}$ Experimental work is performed until $800^{\circ} \mathrm{C}$. Kinetic parameters are determined for reactions taking place until $600^{\circ} \mathrm{C}$

${ }^{2}$ Not reported

${ }^{3}$ Mass fractions $y_{i}$ are normalized to dry and ash-free basis

${ }^{4}$ Kinetic parameters calculated using the Kissinger isoconversional method of each reaction curve obtained by deconvolution of the experimental data

${ }^{5}$ The first reaction proposed in this work corresponds to the drying process of the sewage sludge sample. The parameters of this reaction are not reported here

${ }^{6} \mathrm{R} 1$ to $\mathrm{R} 6$ correspond to each independent parallel reaction used for the kinetik analysis

\subsection{Experimental facility and procedure}

Experiments were carried out in a macro TGA equipped with a continuous evolved gas analysis system (EGA), as shown in Figure 1 . In the following description the numbers refer to this figure. The cylindrical reactor is made of quartz glass and consists of a vertical cylinder and a sealing piece inserted at its top. The crucible hangs together with a quartz glass support from the balance (1). The sample temperature was measured with a K-type thermocouple placed inside the crucible, as shown in the detail of Figure 1 . The reactor was externally heated by the electric furnace (2). Nitrogen 5.0 was used as carrier gas and fed at the top of the reactor through two mass flow controllers MFC1 and MFC2. The gas phase was evacuated at the bottom of the reactor and directed toward the tar condensers TC1 and TC2, where it was cooled down (between $0^{\circ} \mathrm{C}$ to $3^{\circ} \mathrm{C}$ ) and separated from the condensed phase. Afterward, a fraction of the noncondensable gases passed through the continuous gas analysis system, composed of three analyzers for the measurement of $\mathrm{H}_{2}$ and $\mathrm{CH}_{4}(3), \mathrm{CO}$ and $\mathrm{CO}_{2}(4)$ and $\mathrm{O}_{2}$ (5). $\mathrm{O}_{2}$ was used as control value for the conservation of the inert atmosphere during the experiments. Then, the total gas flow was conducted to the gas meter (6). All measurements were recorded using the data acquisition module (7) and a computer. 
Table 2: Fuel characterization, structural characterization and mineral matter composition of the sewage sludge used in this study, and data reported in the literature for comparison purposes. Standard deviations are calculated using three experimental replications.

\begin{tabular}{|c|c|c|c|c|}
\hline \multicolumn{5}{|c|}{ Proximate analysis/wt\% } \\
\hline & $\begin{array}{l}\text { Standard/Equipment (this } \\
\text { study) }\end{array}$ & Colombia (this study) & $\begin{array}{l}\text { Spain Calvo et al. } \\
\text { (2004) }\end{array}$ & $\begin{array}{l}\text { Turkey Karaca et al. } \\
\text { (2018) }\end{array}$ \\
\hline$M_{\mathrm{SS}, \mathrm{ar}}$ & EN 14774-3 & $66.7 \pm 0.5$ & n.r. ${ }^{4}$ & n.r. \\
\hline$M_{\mathrm{SS}, \mathrm{ad}}$ & EN 14774-3 & $9.9 \pm 0.2$ & 7.9 & 6.0 \\
\hline$V_{S S, d}$ & EN 15148 & $45.3 \pm 0.5$ & 42.9 & 55.5 \\
\hline$A_{\mathrm{SS}, 550, \mathrm{~d}}$ & EN 14775 & $56.2 \pm 0.2$ & 53.8 & 35.5 \\
\hline$A_{\mathrm{SS}, 700, \mathrm{~d}}$ & EN $14775^{1}$ & $53.7 \pm 0,2$ & n.r. & n.r. \\
\hline$A_{\mathrm{SS}, 800, \mathrm{~d}}$ & EN $14775^{1}$ & $50.4 \pm 0.2$ & n.r. & n.r. \\
\hline$A_{\mathrm{SS}, 900, \mathrm{~d}}$ & EN $14775^{1}$ & $47.2 \pm 0.2$ & n.r. & n.r. \\
\hline \multicolumn{5}{|c|}{ Elemental analysis/wt\% } \\
\hline $\mathrm{H}_{\mathrm{HSS}, \mathrm{d}}$ & EN15104 & $3.9 \pm 0.2$ & 3.3 & 4.3 \\
\hline $\mathrm{C}_{\mathrm{HSS}, \mathrm{d}}$ & EN15104 & $29.5 \pm 0.4$ & 22.7 & 34.1 \\
\hline $\mathrm{N}_{\mathrm{HSS}, \mathrm{d}}$ & EN15104 & $3.4 \pm 0.2$ & 3.1 & 5.3 \\
\hline $\mathrm{S}_{\mathrm{HSS}, \mathrm{d}}$ & ASTM D516 & $3.4 \pm 0.2$ & 0.9 & 1.0 \\
\hline $\mathrm{O}_{\mathrm{HSS}, \mathrm{d}}{ }^{2}$ & - & $12.6 \pm 0.2$ & 16.1 & 19.7 \\
\hline $\mathrm{TOC}^{3}$ & AnalyticJena N/C3100 & $15.6 \pm 0.4$ & n.r. & n.r. \\
\hline $\mathrm{LHV}_{\mathrm{d}} / \mathrm{MJ} / \mathrm{kg}$ & ASTM D240 & $11.3 \pm 0.1$ & 8.8 & 13.5 \\
\hline \multicolumn{5}{|c|}{ Structural composition/wt\%, dry } \\
\hline & $\begin{array}{l}\text { Standard/Equipment (this } \\
\text { study) }\end{array}$ & Colombia (this study) & $\begin{array}{l}\text { China Wang et al. } \\
\text { (2016) }\end{array}$ & $\begin{array}{c}\text { USA Wesenbeeck et } \\
\text { al. (2014) }\end{array}$ \\
\hline Cellulose & van Soest et al., 1991 & 4.5 & n.r. & n.r. \\
\hline Hemicellulose & van Soest et al., 1991 & 5.7 & n.r. & n.r. \\
\hline Lignin & van Soest et al., 1991 & 15.4 & n.r. & n.r. \\
\hline \multicolumn{5}{|c|}{ Heavy metals content $/ \mathrm{mg} / \mathrm{kg}_{\mathrm{ss}}$, dry } \\
\hline As & \multirow{6}{*}{$\begin{array}{c}\text { Spectrometer Thermo } \\
\text { Electron Corporation S4 } \\
\text { AA-Serie }\end{array}$} & $450.0 \pm 4.2$ & 1983.8 & 67.6 \\
\hline $\mathrm{Cd}$ & & $<1.0$ & 1.7 & 3.6 \\
\hline $\mathrm{Cu}$ & & $990.0 \pm 5.3$ & 3323.9 & 443 \\
\hline $\mathrm{Hg}$ & & $<1.0$ & n.r. & 0.27 \\
\hline $\mathrm{Pb}$ & & $290.0 \pm 2.7$ & 69.7 & 41 \\
\hline \multirow[t]{3}{*}{$\mathrm{Zn}$} & & $4800.0 \pm 21.3$ & 2424.2 & 1360 \\
\hline & \multicolumn{3}{|c|}{ Mineral composition/wt\%, dry } & \\
\hline & $\begin{array}{c}\text { Standard/Equipment (this } \\
\text { study) }\end{array}$ & Colombia (this study) & China Tang et al. (2018) & $\begin{array}{c}\text { USA Wesenbeeck et } \\
\text { al. (2014) }\end{array}$ \\
\hline $\mathrm{SiO}_{2}$ & \multirow{8}{*}{$\begin{array}{l}\text { X Ray fluorescence } \\
\text { spectrometer Philips ref. } \\
\text { MagicX PRO PW-2440 }\end{array}$} & 22.3 & 5.4 & 13.4 \\
\hline $\mathrm{Fe}_{2} \mathrm{O}_{3}$ & & 17.9 & 1.8 & 23.3 \\
\hline $\mathrm{CaO}$ & & 6.9 & 5.3 & 9.1 \\
\hline $\mathrm{Al}_{2} \mathrm{O}_{3}$ & & 6.4 & 4.3 & 4.8 \\
\hline $\mathrm{P}_{2} \mathrm{O}_{5}$ & & 6.1 & 6.6 & 21.3 \\
\hline $\mathrm{TiO}_{2}$ & & 0.7 & 0.2 & 1.2 \\
\hline $\mathrm{MgO}$ & & 0.6 & 1.0 & 3.7 \\
\hline $\mathrm{K}_{2} \mathrm{O}$ & & 0.6 & 1.1 & 2.4 \\
\hline
\end{tabular}

${ }^{1}$ Modified according to the indicated final temperature

${ }^{2}$ Calculated by difference using the ash content determined at $960^{\circ} \mathrm{C}$

${ }^{3}$ Total organic carbon

${ }^{4}$ n.r. Not reported

The experimental procedure started by weighting and placing the sample in the crucible, followed by assembling of the experimental setup. The flow of $\mathrm{N}_{2}$ is fixed in MFC1 and MFC2 and the system was purged until measuring $\mathrm{O}_{2}$ fractions lower than $0.05 \%$. The heating program included a first drying stage where the sample was heated to $105^{\circ} \mathrm{C}$ until constant weight was obtained ( $40 \mathrm{~min}$ to $50 \mathrm{~min}$ ). Afterwards, the temperature is increased using a constant heating rate until a final temperature of $960^{\circ} \mathrm{C}$. This temperature was maintained during $30 \mathrm{~min}$. The sample

was then cooled down until room temperature under inert atmosphere. The char was removed from the reactor and weighed (with a precision of $0.1 \mathrm{mg}$ ).

\subsection{Experimental plan}

Experimental conditions to minimize heat and mass transfer effects and the occurrence of secondary reactions during pyrolysis were initially determined. A particle size between $0.18 \mathrm{~mm}$ and $0.25 \mathrm{~mm}$, a bed height of $2 \mathrm{~mm}$ (corresponding to a dried sample of approx. $1 \mathrm{~g}$ ) and 
nitrogen flows of $0.3 \mathrm{l} / \mathrm{min}$ for MFC1 and $0.9 \mathrm{l} / \mathrm{min}$ for MFC2 (at environmental conditions) were used. Pyrolysis experiments using heating rates of $3 \mathrm{~K} / \mathrm{min}, 5 \mathrm{~K} / \mathrm{min}, 7$ $\mathrm{K} / \mathrm{min}, 10 \mathrm{~K} / \mathrm{min}$ and $12 \mathrm{~K} / \mathrm{min}$ until $960^{\circ} \mathrm{C}$ were carried out (at the heating rate of $10 \mathrm{~K} / \mathrm{min}$, experiments until $570^{\circ} \mathrm{C}$ are made in order to obtain solid samples for analysis). Reproducibility of experiments was determined by repetitions at $3 \mathrm{~K} / \mathrm{min}$ and $10 \mathrm{~K} / \mathrm{min}$. Differences lower than $3.2 \%$ were obtained in the mass loss curves.

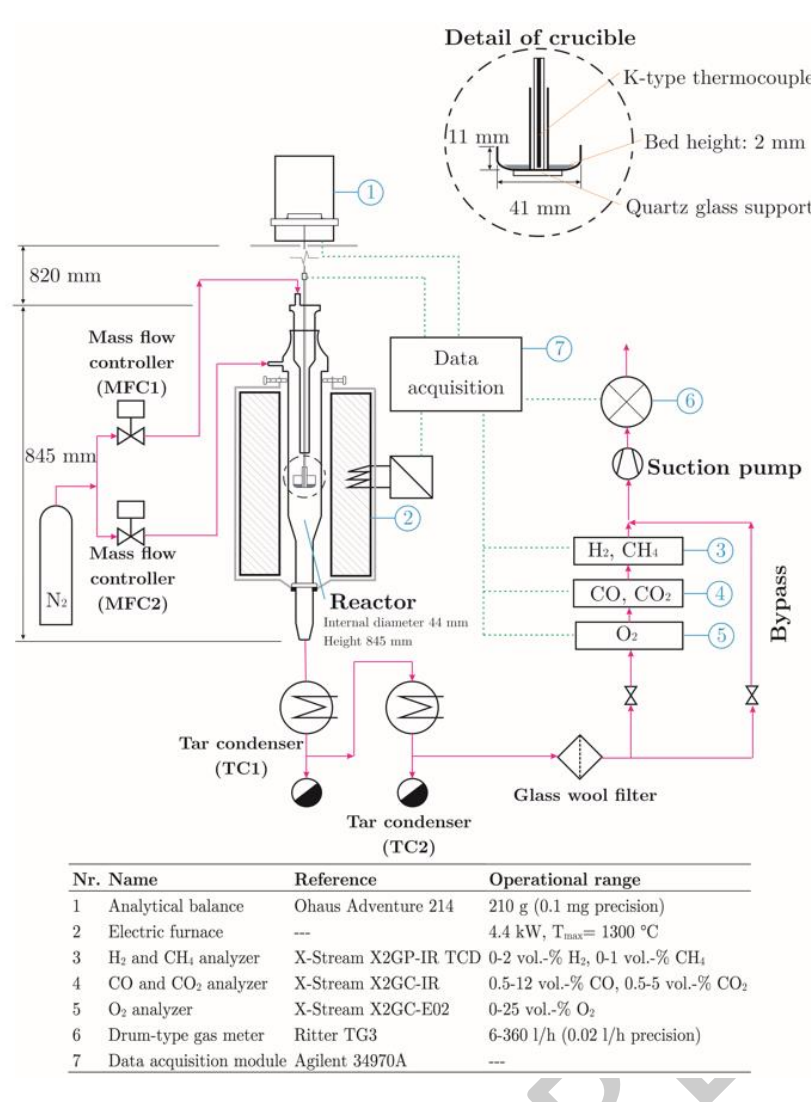

Figure 1 Experimental facility: Macro TGA equipped with evolved gas analysis (EGA).

\subsection{Data analysis and calculations}

Mass signal of the balance was corrected due to the force exerted on the crucible by the downward flow of nitrogen through blank measurements. Mass flows of $\mathrm{CO}, \mathrm{CO}_{2}, \mathrm{CH}_{4}$ and $\mathrm{H}_{2}$ were determined assuming ideal gas behavior of the gas mixture. The mass fraction of the liquid product (water + organic liquid) and its elemental composition were calculated by difference using the fractions of solid and gas products obtained at the temperature at which decomposition of organic matter is completed (established from the experimental results). The water content of the liquid product was determined using the approximation proposed by (Neves et al., 2011). They stated that the mass fractions of $\mathrm{C}, \mathrm{H}$ and $\mathrm{N}$ of the feedstock and those of the organic liquid (in ash-free and dry basis) are correlated in processing under conditions that avoid heat and mass transfer limitations. The values are slightly dependent on pyrolysis final temperature and for $570^{\circ} \mathrm{C}$ they ascend to 1.16 for $w_{\mathrm{C}, \mathrm{SS}, \mathrm{daf}} / w_{\mathrm{c}, \mathrm{Ol}, \mathrm{daf}} ; 0.8$ for $w_{0, S S, d a f} / w_{0, O l, d a f}$ and 1.14 for $w_{\mathrm{H}, S \mathrm{~S}, \mathrm{daf}} / w_{\mathrm{H}, \mathrm{Ol}, \mathrm{daf}}$. The water content was calculated as the amount that minimizes the difference of these values and those obtained using the experimental data.

Normalized mass loss of the sewage sludge $\left(w_{s s, d}\right)$ was calculated using the corrected mass signal of the balance $\left(m_{\mathrm{s}, \mathrm{d}}\right)$ and the initial mass of the sewage sludge in dry basis $\left(m_{\mathrm{s}, 0, \mathrm{~d}}\right)$. Mass yields $\left(y_{\mathrm{M}, \mathrm{p}}\right)$ of pyrolysis products were calculated from the mass of each product $\left(m_{p, d}\right)$, according to Eq. (2):

$$
y=\frac{m_{\mathrm{p}, \mathrm{d}}}{m_{\mathrm{ss}, 0, \mathrm{~d}}}
$$

Energy balances were determined at $25^{\circ} \mathrm{C}$ using the low heating value of each material.

\subsection{Kinetic model}

A formal independent parallel reactions model was implemented for the description of the pyrolysis kinetics of sewage sludge. The reaction rate with $\mathrm{N}$ number of pseudo-components can be expressed as in Eq. (3):

$$
\frac{d w_{R M}}{d t}=-\sum_{i=1}^{N} y_{i} k_{0, i} \exp \left(\frac{-E_{a, i}}{R T}\right) w_{R M}^{n_{i}}
$$

where $w_{R M}$ represents the normalized fraction of the reacting mass of each component. The parameters $\left(N, y_{i}\right.$, $E_{\mathrm{a}, \mathrm{i}}, k_{0, \mathrm{i}}$ and $\left.n_{\mathrm{i}}\right)$ were determined by applying a combination of isoconversional methods and a modelparameter fitting method, as follows. First, experimental values of $w_{\text {RM }}$ were determined using Eq. (4),

$$
w_{\mathrm{RM}}=\frac{m_{\mathrm{RM}}}{m_{\mathrm{RM}, 0}}=\frac{m_{\mathrm{S}, \mathrm{dat}}-m_{\mathrm{char}, \mathrm{f} \text { daf }}}{m_{\mathrm{SS}, \mathrm{d}, \mathrm{daf}}-m_{\mathrm{char}, \mathrm{d}, \mathrm{daf}}} .
$$

The experimental mass measured by the balance $\left(m_{s}\right)$ at each point in time corresponds to the sum of the reacting mass $\left(m_{\mathrm{RM}}\right)$ and the mass of the produced solid or char $\left(m_{\text {char }}\right)$. In order to obtain the value of reacting mass, it was assumed that the fraction of char corresponds in all times to the relation $m_{\text {char, }} / m_{\mathrm{ss}, 0}$. Mass values in ash-free basis were calculated using the ash content measured at $960^{\circ} \mathrm{C}$. An initial set of indicative values of activation energies for the pyrolysis of the pseudo-components was determined using the isoconversional methods of FWO and KAS. Their corresponding linear expressions are presented in Eq. (5) and Eq. (6), respectively (Flynn, 1997):

$$
\begin{aligned}
& (\ln \kappa)=\text { Const }-1.052\left(\frac{E_{a}}{R T}\right)_{W_{\mathrm{RM}}} \\
& \left(\ln \frac{\kappa}{T^{2}}\right)=\text { Const }-\left(\frac{E_{a}}{R T}\right)_{W_{\mathrm{RM}}} .
\end{aligned}
$$

The methods were evaluated for $w_{\mathrm{RM}}$ values ranging from $95 \mathrm{wt} \%$ to $5 \mathrm{wt} \%$ using steps of $5 \mathrm{wt} \%$. The obtained values for the activation energies were used afterward in the model fitting-step as target values. An initial number of pseudo-components was established from the number of discernible peaks obtained in the experimental curves of mass loss rate $\left(\mathrm{d} w_{\mathrm{RM}} / \mathrm{dt}\right)$. Based on Eq. 3, a first set of kinetic parameters $E_{a, i}$ and $k_{0, i}$ for each reaction was determined from an Arrhenius diagram 
$\left(\ln \left(\frac{d w_{\mathrm{RM}} / d t}{w_{\mathrm{RM}}^{n}}\right)\right.$ vs.1/T) by linear regression in the time interval in which the analyzed reaction takes place. The reaction order was initially set to $n_{i}=1$ for each reaction. The fraction $y_{i}$ was calculated as the relationship between the peak heights of the theoretical and the experimental curves. The parameters of the last reaction were first determined and then the calculated mass loss and mass loss rates were subtracted from the experimental values. The parameters of the additional reactions were successively determined using the same procedure. In this way, influences caused by parallel reactions occurring in the same temperature interval are minimized. After determining the first set of initial parameters values, a minimization procedure was performed. The peak position and area of the corresponding reaction were varied simultaneously to obtain a minimum error between the experimental and the calculated differential mass curves by varying $E_{\mathrm{a}, \mathrm{i}}, k_{0, \mathrm{i}}$ and $n_{\mathrm{i}}$. The quality of the minimization was evaluated by the least squares method, calculating the residual sum of squares (RSS) and the fit of the experimental and calculated curves using Eq. (7) and (8), respectively (where $z$ corresponds to the number of data acquired during experimentation):

$$
\begin{aligned}
& R S S=\sum_{1}^{z}\left(\left(d w_{\mathrm{RM}} / d t\right)_{\mathrm{exp}}-\left(d w_{\mathrm{RM}} / d t\right)_{\mathrm{cal}}\right)^{2} ; \\
& \mathrm{Fit}=\sqrt{\frac{R S S}{z}} .
\end{aligned}
$$

The mass of products obtained during sewage sludge pyrolysis was determined using Eq. (9) as the sum of the contributions of the products of the decomposition of each pseudo-component:

$$
y_{M, p}=\sum_{i=1}^{N} y_{M, p, i}
$$

Product evolution of each pseudo-component was estimated using the global stoichiometric model presented in Eq. (10) and the condition of Eq. (11):

$$
\begin{aligned}
& \mathrm{SS}_{\mathrm{i}, \mathrm{RM}} \stackrel{i}{\rightarrow} x_{\mathrm{S}, \mathrm{i}} \mathrm{S}_{\mathrm{d}, \mathrm{daf}}+x_{\mathrm{L}, \mathrm{L}} \mathrm{L}_{\mathrm{d}, \mathrm{daf}}+x_{\mathrm{CO}, \mathrm{i}} \mathrm{CO}_{\mathrm{i}, \mathrm{daf}} \\
& +x_{\mathrm{CO}_{2}, \mathrm{i}} \mathrm{CO}_{2, \mathrm{~d}, \mathrm{daf}}+x_{\mathrm{CH}_{4}, \mathrm{i}} \mathrm{CH}_{4, \mathrm{daf}}+x_{\mathrm{H}_{2}, \mathrm{i}} \mathrm{H}_{2, \mathrm{~d} \text { daf }}, \\
& y_{i}=x_{\mathrm{S}, \mathrm{i}}+x_{\mathrm{L}, \mathrm{i}}+x_{\mathrm{CO}, \mathrm{i}}+x_{\mathrm{CO}_{2}, \mathrm{i}}+x_{\mathrm{CH}_{4}, \mathrm{i}}+x_{\mathrm{H}_{2}, \mathrm{i}}
\end{aligned}
$$

The stoichiometric coefficients $x_{\mathrm{S}, \mathrm{i}}, x_{\mathrm{L}, \mathrm{i}}, x_{\mathrm{CO}^{\mathrm{i}} \mathrm{i}}, x_{\mathrm{CO}_{2}, \mathrm{i}}, x_{\mathrm{CH}_{4}, \mathrm{i}}, x_{\mathrm{H}_{2}, \mathrm{i}}$ were calculated by minimizing the difference between the experimental evolution of each species and the simulated mass flow rates. The coefficient $x_{\mathrm{L}, \mathrm{i}}$ for the liquid product was calculated by difference.

\section{Results and discussion}

\subsection{Thermal decomposition of sewage sludge}

Figure 2(a) shows the mass loss and the mass loss rate (as $\left.\mathrm{d} w_{\mathrm{SS}, \mathrm{d}} / \mathrm{d} T\right)$ of the sewage sludge thermal decomposition until $960^{\circ} \mathrm{C}$ for heating rates between $3 \mathrm{~K} / \mathrm{min}$ and 12
$\mathrm{K} / \mathrm{min}$. The evolved mass curves of gaseous products and their mass production rate at $10 \mathrm{~K} / \mathrm{min}$ are presented in Figure 2(b) and (c). Thermal decomposition can be divided in two zones: A low temperature zone (Zone I) from $120^{\circ} \mathrm{C}$ until a temperature between $550^{\circ} \mathrm{C}$ and $590^{\circ} \mathrm{C}$ and a high temperature zone (Zone II), for temperatures between the end of zone I until $960^{\circ} \mathrm{C}$. Zone I can be mainly attributed to decomposition of organic matter. Temperatures in the range between $500^{\circ} \mathrm{C}$ and $550^{\circ} \mathrm{C}$ have been reported as the final values for thermal degradation of lignocellulosic biomass, lipids and proteins (Arenas et al., 2019; Cortés and Bridgwater, 2015; Zhu, 2019). In zone II, mainly the decomposition of inorganic matter and secondary decomposition reactions of primary char and tar take place (Antal et al., 1998; Casajus et al., 2009; Karayildirim et al., 2006; Thipkhunthod et al., 2007). The influence of the heating rate variation on the process is small in the range studied in this work, being more pronounced in the low temperature zone. With increasing heating rate, a reaction shift to higher temperatures in the whole temperature range is observed. This behavior has been attributed to a shorter exposure time to temperature, causing that the decomposition partially occurs at higher temperatures (Antal et al., 1998). An increasing difference between the measured and the true sample temperatures (thermal lag) have been also detected when the heating rate increases. Consequently, the temperature at which the transition between zone I and zone II takes place slightly increases with an increase in the heating rate. At 3 $\mathrm{K} / \mathrm{min}$, the measured transition takes place at $550^{\circ} \mathrm{C}$, while at $12 \mathrm{~K} / \mathrm{min}$, it occurs at $585^{\circ} \mathrm{C}$. Other works on pyrolysis of sewage sludge in TGA report values between $500^{\circ} \mathrm{C}$ and $677^{\circ} \mathrm{C}$ (Casajus et al., 2009; García et al., 2009; Urych and Smolinski, 2016; Zhu et al., 2019) for this transition.

The following paragraphs present a description of the course of the thermal decomposition based on the results at $10 \mathrm{~K} / \mathrm{min}$. In zone I, the mass loss rate curve shows a shoulder at temperatures lower than $240^{\circ} \mathrm{C}$ and two distinguishable peaks at $340^{\circ} \mathrm{C}$ and $430^{\circ} \mathrm{C}$. Thermal degradation below $250^{\circ} \mathrm{C}$ is typically attributed to organic compounds with low stability, non-biological substances, dead bacteria and simple lipids and aminoacids, among others (Calvo et al., 2004; Font et al., 2005; Thipkhunthod et al., 2007, Urban and Antal, 1982; Urych and Smolinski 2016). Thermal decomposition of these compounds is included in the first decomposition reaction of organic matter in the kinetic studies shown in Table 1. Hemicellulose, whose decomposition starts at temperatures as low as $200^{\circ} \mathrm{C}$ (Yang et al., 2007; Zhu et al., 2019), is included either in the first reaction or as a single compound in reaction R2 (Calvo et al., 2004; García et al., 2009). Font et al., 2005 attributed the first reaction to hemicellulose and the second reaction to dead bacteria. The second global reaction of decomposition occurs approximately between $220^{\circ} \mathrm{C}$ and $400^{\circ} \mathrm{C}$, as shown in Figure 2(a). In addition to hemicellulose, at these temperatures, cellulose, lignin and proteins decomposition takes place (Yang et al., 2007; Varhegy et al., 2007; Thipkhunthod et al., 2007). Above $400^{\circ} \mathrm{C}$, 
decomposition is caused mainly by lignin (Yang et al., 2007) and lipids (Thipkhunthod et al., 2007, Zhu et al., 2019). Xu et al., 2018 attributed reaction R3 to aromatic compounds and polyphenols. Mass loss in zone I can also be affected by decomposition of other organic compounds present in smaller quantities, such as starch, humic acids, nucleic acids, coagulants, plastics and fractions of waste tires (Thipkhunthod et al., 2007; Wang et al., 2019), and to decomposition of inorganic compounds with low decomposition temperatures.

Regarding gas evolution, the predominant gas species is $\mathrm{CO}_{2}$, followed by $\mathrm{CO}$ (Figure 2(b)). $\mathrm{CH}_{4}$ and $\mathrm{H}_{2}$ account for a small fraction of the total gas production (Figure 2(c)). The mass production rates of $\mathrm{CO}_{2}$ and $\mathrm{CO}$ show a peak, each with maximum rates at $405^{\circ} \mathrm{C}$ and $420^{\circ} \mathrm{C}$, respectively. The formation of these peaks can be attributed mainly to protein and lignin decomposition, as $\mathrm{CO}_{2}$ and $\mathrm{CO}$ production from hemicellulose and cellulose occurs at lower temperatures, and production of lipids at higher ones. Moreover, lime ( $\mathrm{CaO})$, which is added during sewage treatment and is present in a considerable amount in the ash of the analyzed sample (see Table 2), can absorb $\mathrm{CO}_{2}$ evolved in this zone (Chanaka et al., 2019b). $\mathrm{CH}_{4}$ formation is mainly associated with primary pyrolysis reactions of lignin and with decomposition of proteins (due to dead bacteria) at temperatures below $500^{\circ} \mathrm{C}$ (Gao et al., 2014; Yang et al., 2007). $\mathrm{H}_{2}$ evolution shows the typical course observed during pyrolysis of lignocellulosic biomass.

In zone II, from $570^{\circ} \mathrm{C}$ onward, a continuous increment in the mass loss rate is detected (Figure 2 (a)). This increment takes place simultaneously with an increase in the gas evolution caused mainly by $\mathrm{CO}$ and $\mathrm{CO}_{2}$, as presented in Figure 2 (b) and (c). Decomposition of inorganic matter in zone II is included in the models of (García et al., 2009; Urych and Smolinski 2016) (Table 1), but no reference to the involved compounds is made. As shown in Table 2, iron and silicon are found in larger amounts in the sample, followed by calcium, aluminum and phosphorus. $\mathrm{CO}_{2}$ evolution between $600^{\circ} \mathrm{C}$ and $800^{\circ} \mathrm{C}$ can be associated with decomposition of calcium carbonate $\mathrm{CaCO}_{3}$ to $\mathrm{CaO}$ (Karayildirim et al., 2006). Part of this $\mathrm{CO}_{2}$ could have been originated and adsorbed by $\mathrm{CaO}$ in zone I. The release of $\mathrm{CO}$ between $570^{\circ} \mathrm{C}$ and $960^{\circ} \mathrm{C}$, observed in Figure 2(b), can be attributed to three pathways: First, the reaction of $\mathrm{Fe}_{3} \mathrm{O}_{4}$ with $\mathrm{C}$ to $\mathrm{Fe}$ and $\mathrm{CO}$ (Furimsky and Sears, 1988). Second, char gasification inside the char particles according to the Boudouard reaction favoring the formation of $\mathrm{CO}$ at the expense of $\mathrm{CO}_{2}$. Third, thermal cracking of hydrocarbons filling the porous structure of the solid phase. This reaction causes at the same time the decrease of $\mathrm{CH}_{4}$ and the steep increase in $\mathrm{H}_{2}$ observed at temperatures higher than $650^{\circ} \mathrm{C}$ (Chanaka et al., 2019a; Morf, 2002). Pathways 2 and 3 are catalyzed in the presence of $\mathrm{CaO}$ (Chanaka et al., 2019a). Additionally, dehydrogenation reactions that occur at temperatures above $450^{\circ} \mathrm{C}$ Porada, 1959 can also contribute to $\mathrm{H}_{2}$ formation. Silicon and aluminum are present as oxides or as silicates and aluminosilicates of metals (for the analyzed sample, mainly of $\mathrm{Ca}$ and Fe and in a minor proportion of $\mathrm{Mg}$ and $\mathrm{K}$ ). These compounds undergo solid state transformations at high temperatures without the release of gaseous species or are stable in the temperature range studied (i.e. $\mathrm{SiO}_{2}$ and $\mathrm{Al}_{2} \mathrm{O}_{3}$ ) (Roedder, 1959). A small influence on $\mathrm{CO}_{2}$ formation may arise from the reaction of silicon oxide with potassium carbonate to form potassium silicates (Roedder, 1959). Although the influence of silicates and aluminosilicates in the pyrolysis process has not been deeply studied, they play an important role in heavy metal immobilization in the solid product by the formation of thermally stable, acid insoluble compounds (Chanaka et al., 2019a, 2019b).
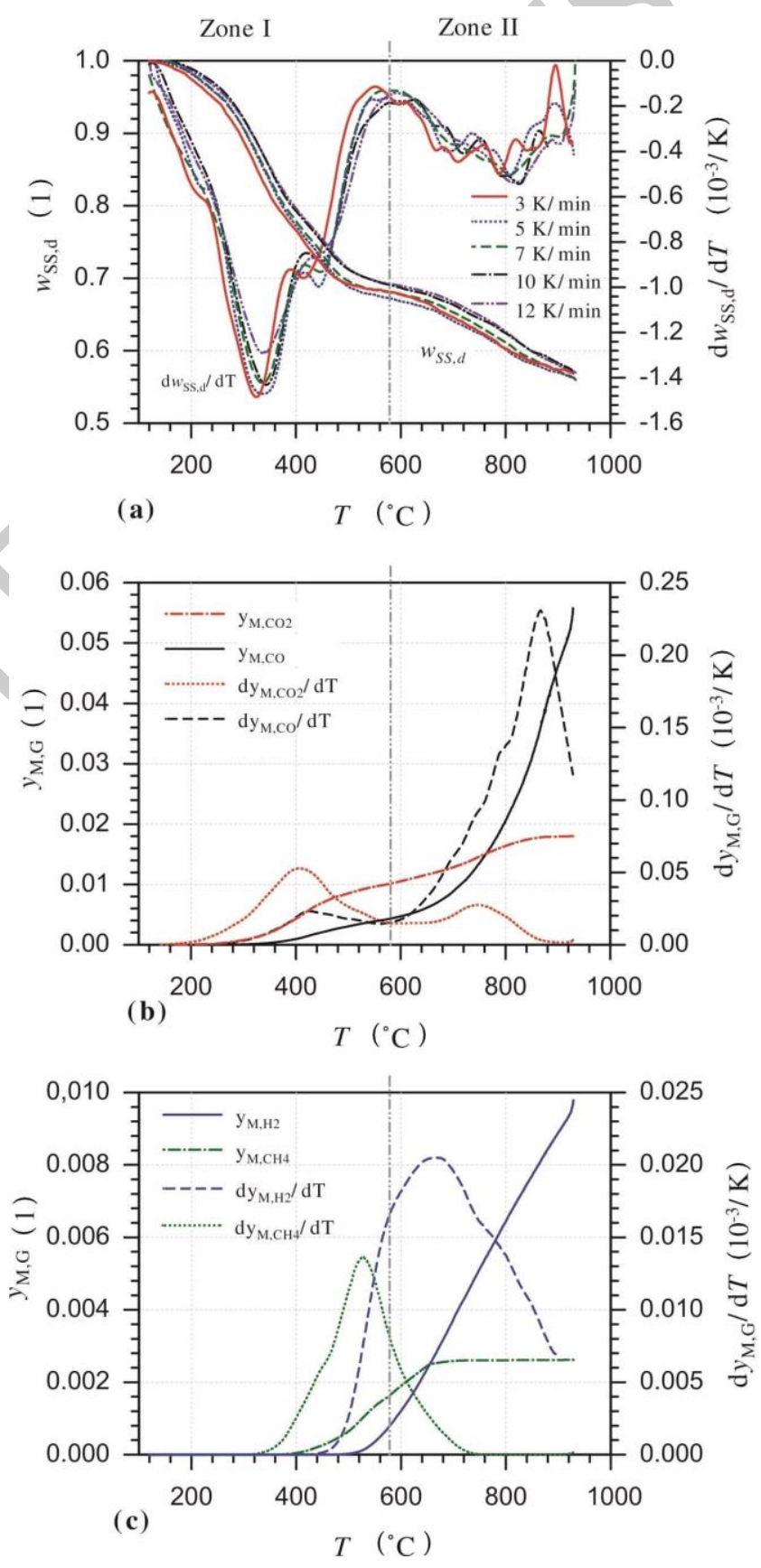

Figure 2 Mass loss and mass loss rate at different heating rates (a), mass production rate and mass production of $\mathrm{CO}$ and $\mathrm{CO}_{2}$ (b), and mass production rate and mass production of $\mathrm{H}_{2}$ and $\mathrm{CH}_{4}$ (c) during sewage sludge pyrolysis at $10 \mathrm{~K} / \mathrm{min}$ until a final temperature of $960^{\circ} \mathrm{C}$. 


\subsection{Mass and energy balances}

Figure 3 shows Sankey diagrams for the mass and energy balances for the pyrolysis of sewage sludge at $10 \mathrm{~K} / \mathrm{min}$ until $570^{\circ} \mathrm{C}$ and between $570^{\circ} \mathrm{C}$ and $960^{\circ} \mathrm{C}$. Errors in mass and energy balances are presented as differences in these diagrams. Detailed results of mass and elements balances are included in Tables 4 and 5 in the Appendix A. Mass loss of sewage sludge in dry basis during pyrolysis until $960^{\circ} \mathrm{C}$ amounts to $43.1 \mathrm{wt} \%$. A fraction of $71.4 \mathrm{wt} \%$ of this decomposition (30.8 wt\% of the dry sewage sludge mass) takes place in zone I and the rest occurs in zone II. The obtained solid fraction is in the range of the highest values found in the literature, while the gaseous fraction is around the lowest (Álvarez et al., 2015; Trinh et al., 2013). The liquid fraction is between the average of the reported values (Álvarez et al., 2015; Sánchez et al., 2009). Its calculated water content according to section 2.4 amounts to $18.2 \mathrm{wt} \%$. Reported values of water content for this fraction vary between $10 \mathrm{wt} \%$ and $65 \mathrm{wt} \%$ (in dry basis) (Rincón et al., 2019; Sánchez et al., 2009; Trinh et al., 2013; Urych and Smolinski, 2016). The extent to which thermal decomposition of inorganic matter in zone II takes place is approximately determined as follows: Solid losses 17.8 wt\% of its mass in this zone. Under the supposition that the same amount of mineral matter decomposes at combustion and at pyrolysis conditions, the difference between the ash content measured at $550^{\circ} \mathrm{C}$ and that at $960^{\circ} \mathrm{C}$ (see Table 2) equals the volatilized mineral matter in this zone. Its value amounts to $9 \mathrm{wt} \%$ of the initial sewage sludge mass or $13 \mathrm{wt} \%$ of Solid $_{1}$ and corresponds to 73 wt\% (13 wt\%/17.8 wt\%) of the mass loss of Solid ${ }_{1}$. The remaining 27 wt $\%$ of this mass loss is then caused by secondary reactions of the residual organic matter. Ash contents of $68.2 \mathrm{wt} \%$ and of $82.9 \mathrm{wt} \%$ are calculated for Solid $_{1}$ and Solid $_{2}$, respectively. Total mineral matter of Solid $_{1}$, determined as the sum of volatile mineral matter and ash, amounts to $81.2 \mathrm{wt} \%$. In terms of the element balances, the mass of carbon after pyrolysis up to $570^{\circ} \mathrm{C}$ is approximately evenly distributed in the solid and liquid products. 73 wt\% of the mass of hydrogen and $70 \mathrm{wt} \%$ of the mass of oxygen originally present in the dried sewage sludge are in the liquid product after pyrolysis. After subsequent heating to $960^{\circ} \mathrm{C}, 25 \mathrm{wt} \%$ of the mass of carbon present in the sewage sludge remains in the solid product, while hydrogen and oxygen pass almost completely into the gaseous phase.

The $L H V$ in dry basis of each material presented in Figure 3(b) are 7.77 MJ/kg for Solid $1,5.19 \mathrm{MJ} / \mathrm{kg}$ for Solid $2,12.16$ $\mathrm{MJ} / \mathrm{kg}$ for $\mathrm{Gas}_{1}, 24.29 \mathrm{MJ} / \mathrm{kg}$ for $\mathrm{Gas}_{2}$ and $33.42 \mathrm{MJ} / \mathrm{kg}$ for organic liquid. From the energy balance, a value of 2.18 $\mathrm{MJ} / \mathrm{kg}$ of dry sewage sludge, or $19.4 \%$ of its $L H V$, is calculated for the energy required for the pyrolysis until $570^{\circ} \mathrm{C}$. The liquid product (organic liquid plus pyrolysis water) has the highest energy fraction followed by the solid product. The former amounts to $58.5 \%$ and the latter to $40.0 \%$ of the energy entering the process. The energy fraction of the gas product at $570^{\circ} \mathrm{C}$ is negligible. The energy content of the evolved gases in the high temperature zone equals $13.4 \%$ of the energy contained in the dry sewage sludge. The difference in the energy balance originates from the error in the mass balance. As decomposition reactions of inorganic compounds of $\mathrm{Ca}$ and $\mathrm{Fe}$ as well as secondary cracking and gasification reactions are mostly endothermic, an overall endothermic reaction of the process is expected in the high temperature zone.

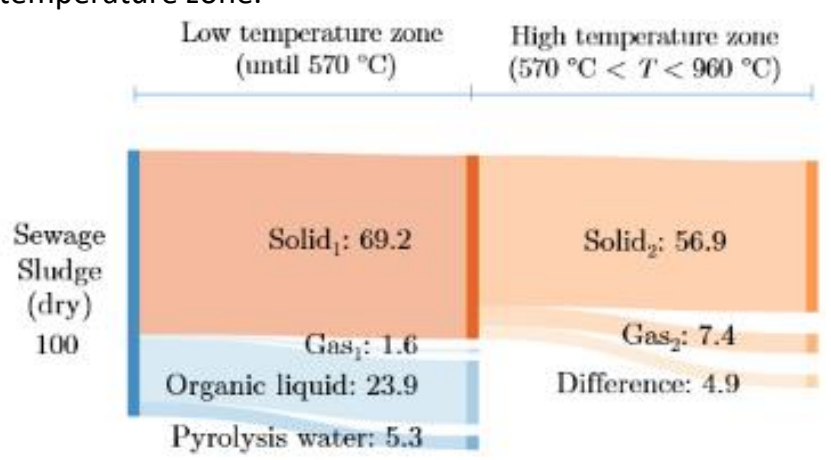

(a) Mass balance $m_{p} / m_{s s, d}(\%)$

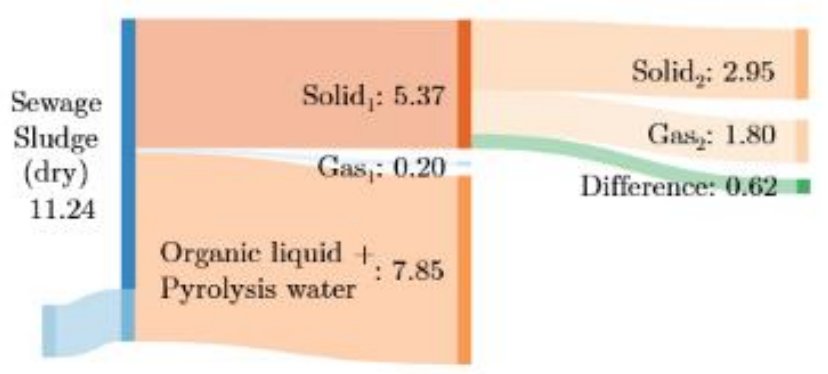

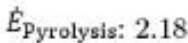

(b) Energy balance $\mathrm{E} / \mathrm{m}_{\mathrm{BS}, \mathrm{d}}(\mathrm{MJ} / \mathrm{kg}$ )

Figure 3 Mass and energy balances for the pyrolysis of sewage sludge at $10 \mathrm{~K} / \mathrm{min}$ until $570^{\circ} \mathrm{C}$ and $960^{\circ} \mathrm{C}$.
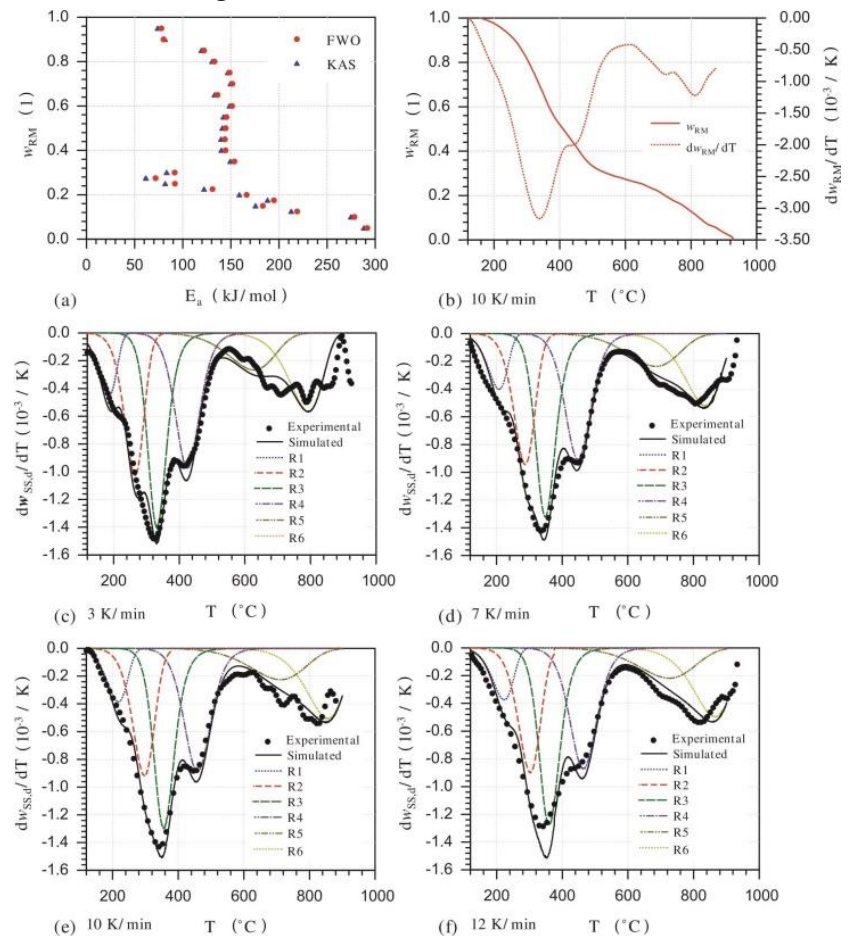

Figure 4 Activation energy values for conversion steps of 5 wt-\% by the FWO and KAS isoconversional methods (a), mass loss $\left(w_{\mathrm{RM}}\right)$ and mass loss rate (as $\left.\mathrm{d} w_{\mathrm{RM}} / \mathrm{d} T\right)$ at $10 \mathrm{~K} / \mathrm{min}(\mathrm{b})$, and experimental and simulated mass loss rate curves of sewage sludge pyrolysis at different heating rates (c to f). 
The low influence of heating rate on product yield, observed in Table 4, is attributed to the high content of mineral matter of the sewage sludge used in this work which exerts a pronounced catalytic effect on the pyrolysis reactions.

\subsection{Implementation of the kinetic model}

Figure $4(\mathrm{a})$ shows the variation of $E_{\mathrm{a}}$ with $w_{\mathrm{RM}}$ obtained from the application of the isoconversional methods of FWO and KAS, according to Eq. (5) and Eq. (6). Experimental values of $w_{\mathrm{RM}}$ and $\mathrm{d} w_{\mathrm{RM}} / \mathrm{d} T$ for $10 \mathrm{~K} / \mathrm{min}$ are shown in Figure 4(b). Arrhenius plots and the values of $E_{a}$, along with the correlation coefficient of each linear fitting, are included in Figure 6 and Table 6 of the Appendix A. Maximal variations in $E_{\mathrm{a}}$, between both methods are around $5 \%$ in zone I and $14 \%$ in zone $\mathrm{II}$, therefore, any of them can be used to obtain the first estimated values of the activation energy for the pyrolysis process at different conversion levels. The variations in $E_{\mathrm{a}}$ with $w_{\mathrm{RM}}$ in the range between $95 \mathrm{wt} \%$ and $70 \mathrm{wt} \%$ (up to about $350^{\circ} \mathrm{C}$ ) and from $25 \mathrm{wt} \%$ until the end of the process (above $600^{\circ} \mathrm{C}$ ) indicate that the overall decomposition is the result of the decomposition of several individual components. On the other hand, narrow variations around a value of $E_{\mathrm{a}}=150 \mathrm{~kJ} / \mathrm{mol}$ for $w_{\mathrm{RM}}$ between 70 $w t \%$ and $35 \mathrm{wt} \%$ (between $350^{\circ} \mathrm{C}$ to $500^{\circ} \mathrm{C}$ ) indicate that the process is dominated in this range by a single compound or that it takes place over several compounds with similar $E_{\mathrm{a}}$. In the transition region between zone I and zone II, the strong decrease in the values of $E_{\mathrm{a}}$ is caused by the completion of the decomposition reactions of the organic matter.

A set of four reactions in zone I and two reactions in zone II appropriately fit the sewage sludge thermal decomposition of the samples used in this study. Table 3 presents the calculated kinetic parameters and the stoichiometric coefficients for the estimation of the simulated curves of mass loss, mass loss rate and product evolution. Figure 4(c) to Figure 4(f) show the comparison of simulated results of $\mathrm{d} w_{\mathrm{ss}, \mathrm{d}} / \mathrm{d} T$ with experimental data for different heating rates. The calculated curves adequately reproduce the experimental mass loss for the heating rates used. The maximal deviation calculated according to Eq. (8) equals $9.0 \%$, mainly due to differences in the peak heights of zone I, which are accentuated by increasing heating rates. According to the analysis presented in section 3, reactions $\mathrm{R} 1$ and $\mathrm{R} 2$ relate to the degradation of extractives and a fraction of hemicellulose. Reactions R3 and R4 are responsible for the decomposition of cellulose, lignin, proteins, lipids and some plastics. Reactions $\mathrm{R} 5$ and $\mathrm{R} 6$ represent the decomposition of volatile inorganic matter and secondary decomposition of residual organic matter. From the studies presented in Table 1 Font et al., 2005 reported a similar variation of $E_{\mathrm{a}}$ with conversion to that found in the present study.

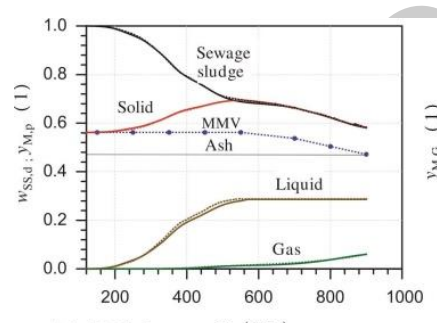

(a) $10 \mathrm{~K} / \mathrm{min} \quad \mathrm{T}\left({ }^{\circ} \mathrm{C}\right)$
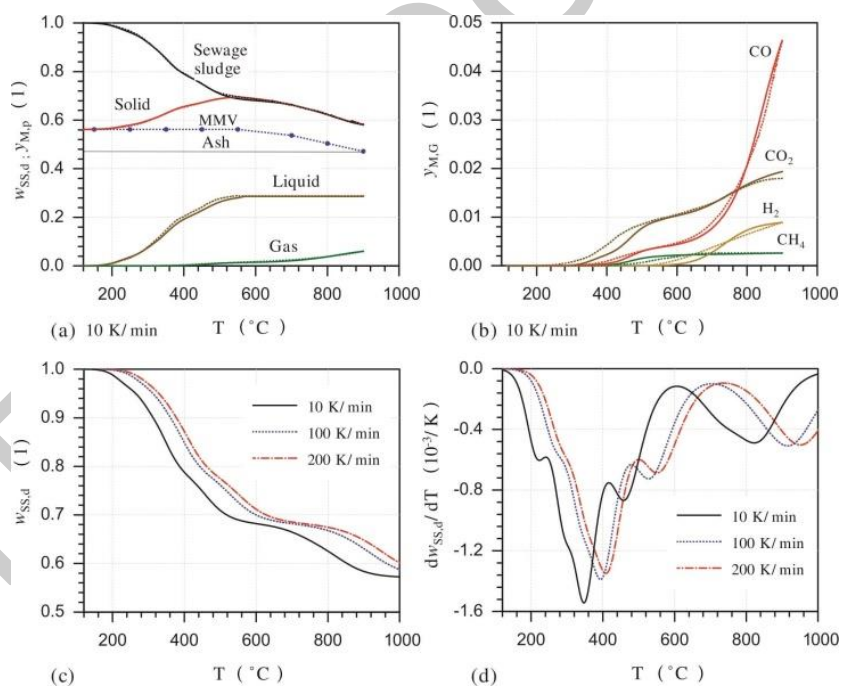

(b) $10 \mathrm{~K} / \mathrm{min} \quad \mathrm{T}\left({ }^{\circ} \mathrm{C}\right)$

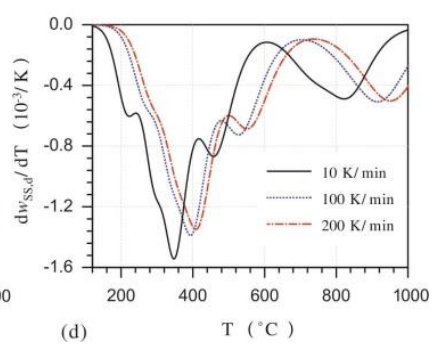

Figure 5 Mass loss and product evolution during the pyrolysis of sewage sludge at $10 \mathrm{~K} / \mathrm{min}$ ( $\mathrm{a}$ and $\mathrm{b}$ ), and simulated curves of mass loss and mass loss rates (as $d w_{\mathrm{SS}, \mathrm{d}} / \mathrm{d} T$ ) (c and $\mathrm{d}$ ) during sewage sludge pyrolysis at $10 \mathrm{~K} / \mathrm{min}, 100 \mathrm{~K} / \mathrm{min}$ and $200 \mathrm{~K} / \mathrm{min}$.

Table 3: Kinetic parameters determined in this study for the independent parallel reactions model of the sewage sludge pyrolysis, and stoichiometric coefficients of products (char (S), liquid (L), $\mathrm{CO}, \mathrm{CO}_{2}, \mathrm{CH}_{4}$ and $\mathrm{H}_{2}$ ) for each independent parallel reactions according to Eq. (10)

\begin{tabular}{|c|c|c|c|c|c|c|}
\hline Reactions & R1 & $\mathbf{R 2}$ & R3 & R4 & R5 & R6 \\
\hline \multicolumn{7}{|c|}{ Kinetic parameters for the independent parallel reactions } \\
\hline$E_{\mathrm{a}, \mathrm{i}} / \mathrm{kJ} / \mathrm{mol}$ & 90.36 & 128.00 & 150.57 & 147.82 & 151.46 & 250.51 \\
\hline $\ln k_{0, i} / 1 / \mathrm{s}$ & 17.20 & 22.42 & 24.07 & 18.80 & 12.23 & 21.50 \\
\hline$y_{i} / 1$ & 0.10 & 0.13 & 0.29 & 0.22 & 0.12 & 0.14 \\
\hline$n_{\mathrm{i}} / 1$ & 2.00 & 1.80 & 2.40 & 2.20 & 1.50 & 2.00 \\
\hline \multicolumn{7}{|c|}{ Stoichiometric coefficients of products } \\
\hline$x_{\mathrm{S}, \mathrm{i}}$ & 0.033 & 0.042 & 0.095 & 0.062 & 0.044 & 0.047 \\
\hline$x_{\mathrm{L}, \mathrm{i}}$ & 0.067 & 0.087 & 0.192 & 0.138 & 0.000 & 0.000 \\
\hline$x_{\mathrm{CO}, \mathrm{i}}$ & 0.000 & 0.001 & 0.001 & 0.007 & 0.011 & 0.041 \\
\hline$x_{\mathrm{CO} 2, \mathrm{i}}$ & 0.000 & 0.000 & 0.003 & 0.011 & 0.007 & 0.002 \\
\hline$x_{\mathrm{CH} 4, \mathrm{i}}$ & 0.000 & 0.000 & 0.000 & 0.003 & 0.000 & 0.000 \\
\hline$x_{\mathrm{H} 2, \mathrm{i}}$ & 0.000 & 0.000 & 0.000 & 0.000 & 0.008 & 0.000 \\
\hline
\end{tabular}

As presented in Figure 5 ( $a$ and $b$ ), simulated and experimental curves of mass loss and evolution of products show good agreement. The change in ash content above $570^{\circ} \mathrm{C}$ is included in the mass loss curve. Figure 5 ( $c$ and $d$ ) show the simulated mass loss and mass loss rate curves (as $d w_{s s, d} / d T$ ) for the pyrolysis of the 
sewage sludge sample analyzed in this study, using higher heating rates of $100 \mathrm{~K} / \mathrm{min}$ and $200 \mathrm{~K} / \mathrm{min}$ (and those for $10 \mathrm{~K} / \mathrm{min}$ for comparison purposes). Since no considerable changes in solid yield with the heating rate are expected, the value obtained at $960^{\circ} \mathrm{C}$ is used for the solid yield needed for the implementation of the model. Even with higher heating rates than those used to determine the set of kinetic parameters, an adequate reproduction of the mass loss curves and their peaks during pyrolysis is obtained. In their experiments in TGA at $100 \mathrm{~K} / \mathrm{min}$, Urych and Smolinski, 2016 measured a transition temperature between zone I and zone II of $700^{\circ} \mathrm{C}$, corresponding to an increment in $75^{\circ} \mathrm{C}$ with respect to the value obtained at 10 $\mathrm{K} / \mathrm{min}$. This test indicates the suitability of the kinetic parameters determined for use at higher heating rates, but their validation requires additional experimental work.

\section{Conclusions}

The pyrolysis of sewage sludge allows the generation of valuable products that can be used as energy source or as raw material for further applications. In the temperature range from $550^{\circ} \mathrm{C}$ to $600^{\circ} \mathrm{C}$, the thermal degradation of most of the organic material is completed. From this temperature and up to high pyrolysis temperatures of $960^{\circ} \mathrm{C}$, further reactions of the solid residue occur. These reactions correspond to volatilization of $\mathrm{Fe}$ - and $\mathrm{Ca}$ compounds and to secondary reactions of remaining organic matter. The product yields are strongly influenced by the final temperature, while the influence of the heating rate is negligible. The yield of the solid residue depends especially on the content of inorganic material. Gas production until $570^{\circ} \mathrm{C}$ amount to just $1.6 \mathrm{wt} \%$ of the initial dry sewage sludge sample, while liquid production amount to $29.2 \mathrm{wt} \%$ and char to $69.2 \mathrm{wt} \%$. An increment in the final temperature to $960^{\circ} \mathrm{C}$ leads to an increase in the gas production to $7.4 \mathrm{wt} \%$ and a reduction in the solid yield to $56.9 \mathrm{wt} \%$.

A reaction enthalpy of $19.4 \%$ of the lower calorific value of the dry sewage sludge is determined for pyrolysis up to $570^{\circ} \mathrm{C}$. Until this temperature the energy entering the process is distributed into fractions of $58.5 \%, 40.0 \%$ and $1.5 \%$ for liquid, solid and gaseous products, respectively. Further increase of the pyrolysis temperature up to $960^{\circ} \mathrm{C}$ causes a decrease in the energy fraction of the solid residue to $22.0 \%$. The energy fraction of the gaseous product generated in this temperature region amounts to $13.4 \%$ of the energy entering the process.

The use of fitting and isoconversional methods coupled in a formal semi-global reaction scheme for pyrolysis allows establishing a set of reaction kinetic parameters suitable for the simulation of the process, which presents an appropriate stability even for heating rates up to 200 $\mathrm{K} / \mathrm{min}$. These results are an important tool for the development and scale-up of the pyrolysis process of sewage sludge in reactors operating at heating rates of this order of magnitude.

\section{Appendix A}

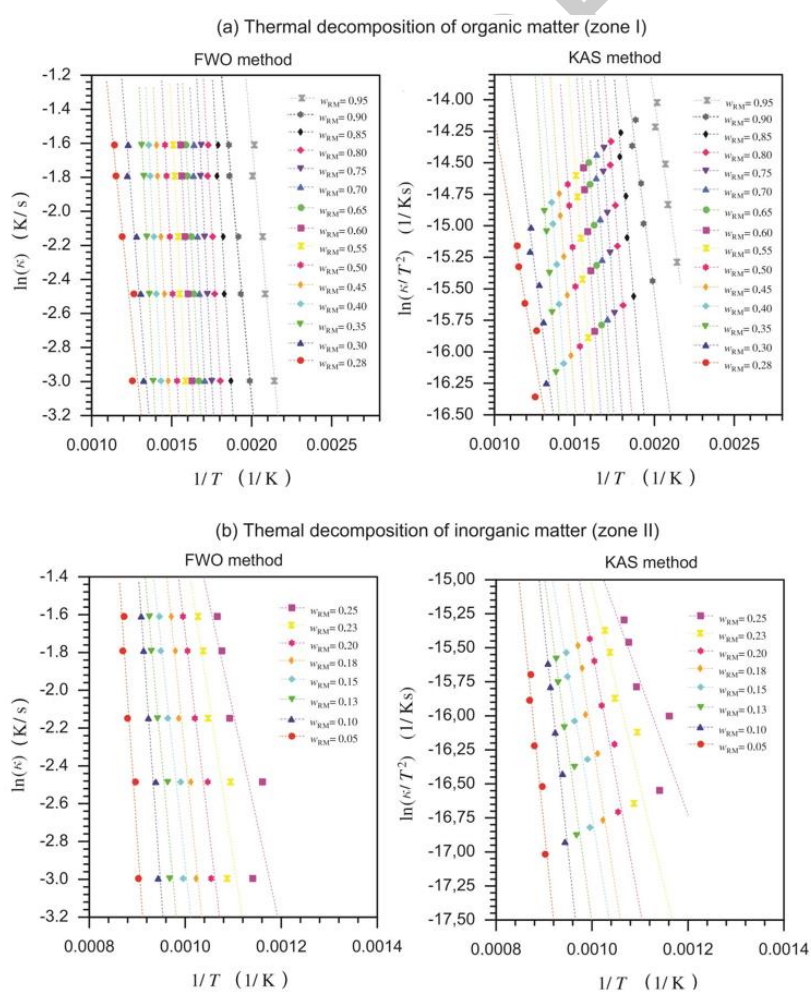

Figure 6: Arrhenius plots for the determination of $E_{\mathrm{a}}$ using the FWO and KAS isoconversional methods.

Table 4: Mass balances for the pyrolysis of sewage sludge at different heating rates until the transition temperature between zone I and zone II and until $960^{\circ} \mathrm{C}$. The mass of the liquid product at $960^{\circ} \mathrm{C}$ is the same as that at the transition temperature since it is assumed that no further changes at high temperatures take place in this phase. All values are in dry basis (S, solid; L, liquid)

\begin{tabular}{|c|c|c|c|c|c|c|c|c|}
\hline & \multirow{2}{*}{ Temperature } & \multicolumn{7}{|c|}{ Product yields/1 } \\
\hline & & $y_{s, d}$ & $y_{\mathrm{L}, \mathrm{d}}$ & $y_{\mathrm{co}, \mathrm{d}}$ & $y_{\mathrm{CO} 2, \mathrm{~d}}$ & $y_{\mathrm{CH} 4 \mathrm{~d}}$ & $y_{\mathrm{H} 2, \mathrm{~d}}$ & Total \\
\hline \multirow{3}{*}{ TG1 (3 K/min) } & $560^{\circ} \mathrm{C}$ & 0.6878 & 0.2984 & 0.0056 & 0.0057 & 0.0010 & 0.0015 & 1.0000 \\
\hline & $960^{\circ} \mathrm{C}$ & 0.5685 & 0.2984 & 0.0637 & 0.0092 & 0.0010 & 0.0094 & 0.9530 \\
\hline & $\Delta y_{p, 960-560^{\circ} \mathrm{C}}$ & -0.1194 & 0.0000 & 0.0582 & 0.0034 & 0.0000 & 0.0079 & -0.0498 \\
\hline \multirow{3}{*}{ TG2 (7 K/min) } & $565^{\circ} \mathrm{C}$ & 0.6822 & 0.2941 & 0.0076 & 0.0117 & 0.0027 & 0.0016 & 1.0000 \\
\hline & $960^{\circ} \mathrm{C}$ & 0.5610 & 0.2941 & 0.0692 & 0.0152 & 0.0030 & 0.0085 & 0.9511 \\
\hline & $\Delta y_{p, 960-565^{\circ} \mathrm{C}}$ & -0.1212 & 0.0000 & 0.0616 & 0.0035 & 0.0003 & 0.0068 & -0.0489 \\
\hline \multirow{3}{*}{ TG3 $(10 \mathrm{~K} / \mathrm{min})$} & $570^{\circ} \mathrm{C}$ & 0.6919 & 0.2917 & 0.0041 & 0.0100 & 0.0016 & 0.0007 & 1.0000 \\
\hline & $960^{\circ} \mathrm{C}$ & 0.5687 & 0.2917 & 0.0588 & 0.0183 & 0.0026 & 0.0106 & 0.9507 \\
\hline & $\Delta y_{p, 960-570^{\circ} \mathrm{C}}$ & -0.1232 & 0.0000 & 0.0547 & 0.0083 & 0.0010 & 0.0099 & -0.0493 \\
\hline
\end{tabular}




\begin{tabular}{ccccccccc}
\hline \multirow{3}{*}{ TG4 (12 K/min) } & $585^{\circ} \mathrm{C}$ & 0.6865 & 0.2939 & 0.0051 & 0.0117 & 0.0022 & 0.0006 & 1.0000 \\
\cline { 2 - 8 } & $960^{\circ} \mathrm{C}$ & 0.5706 & 0.2939 & 0.0522 & 0.0179 & 0.0027 & 0.0099 & 0.9472 \\
\cline { 2 - 9 } & $\Delta y_{\mathrm{p}, 960-585^{\circ} \mathrm{C}}$ & -0.1159 & 0.0000 & 0.0471 & 0.0062 & 0.0005 & 0.0093 & -0.0528 \\
\hline
\end{tabular}

Table 5: Element balances for the pyrolysis of sewage sludge at $10 \mathrm{~K} / \mathrm{min}$ until $570^{\circ} \mathrm{C}$ and $960^{\circ} \mathrm{C}$. Elemental analysis of the liquid product at $960^{\circ} \mathrm{C}$ is the same as that at $570^{\circ} \mathrm{C}$ since its formation is completed at $570^{\circ} \mathrm{C}$

\begin{tabular}{|c|c|c|c|c|c|c|c|c|}
\hline \multicolumn{9}{|c|}{ Final temperature $570^{\circ} \mathrm{C}$} \\
\hline & \multirow[t]{2}{*}{ Sewage sludge } & \multicolumn{7}{|c|}{ Products } \\
\hline & & Solid & Liquid & Co & $\mathrm{CO}_{2}$ & $\mathrm{CH}_{4}$ & $\mathrm{H}_{2}$ & Total \\
\hline & \multicolumn{8}{|c|}{ Element composition based on the dry mass of each product $m_{\text {element }} / m_{\mathrm{p}}$} \\
\hline $\mathrm{C}$ & 0.2947 & 0.2069 & 0.5000 & 0.4288 & 0.2729 & 0.7487 & - & \\
\hline $\mathrm{H}$ & 0.0391 & 0.0134 & 0.0987 & - & - & 0.2513 & 1.000 & \\
\hline $\mathrm{O}$ & 0.1262 & 0.0420 & 0.3001 & 0.5712 & 0.7271 & - & - & \\
\hline $\mathrm{N}$ & 0.0343 & 0.0213 & 0.0670 & - & - & - & - & D \\
\hline \multirow[t]{2}{*}{$\mathrm{S}$} & 0.0338 & 0.0344 & 0.0343 & - & - & - & - & 2 \\
\hline & \multicolumn{8}{|c|}{ Element composition based on the dry mass of sewage sludge $m_{\text {element }} / m_{\mathrm{ss}, \mathrm{d}}$} \\
\hline$y_{C}$ & & 0.1432 & 0.1459 & 0.0018 & 0.0027 & 0.0012 & - & 0.2947 \\
\hline$y_{H}$ & & 0.0093 & 0.0288 & - & - & 0.0004 & 0.0007 & 0.0391 \\
\hline$y_{0}$ & & 0.0290 & 0.0875 & 0.0024 & 0.0073 & - & - & 0.1262 \\
\hline$y_{\mathrm{N}}$ & & 0.0147 & 0.0196 & - & - & - & - & 0.0343 \\
\hline \multirow[t]{5}{*}{$y_{s}$} & & 0.0238 & 0.0100 & - & - & - & - & 0.0338 \\
\hline & \multicolumn{8}{|c|}{ Final temperature $960^{\circ} \mathrm{C}$} \\
\hline & \multirow[t]{2}{*}{ Sewage sludge } & Products & & & & & & \\
\hline & & Solid & Liquid & $\mathrm{CO}$ & $\mathrm{CO}_{2}$ & $\mathrm{CH}_{4}$ & $\mathrm{H}_{2}$ & Total \\
\hline & \multicolumn{8}{|c|}{ Element composition based on the dry mass of each product $m_{\text {element }} / m_{\mathrm{p}}$} \\
\hline $\mathrm{C}$ & 0.2947 & 0.1296 & 0.5000 & 0.4288 & 0.2729 & 0.7487 & - & \\
\hline $\mathrm{H}$ & 0.0391 & 0.0028 & 0.0987 & - & - & 0.2513 & 1.000 & \\
\hline 0 & 0.1262 & 0.0115 & 0.3001 & 0.5712 & 0.7271 & - & - & \\
\hline $\mathrm{N}$ & 0.0343 & 0.0042 & 0.0670 & $2-1$ & - & - & - & \\
\hline \multirow[t]{2}{*}{$\mathrm{S}$} & 0.0338 & 0.0221 & 0.0343 & - & - & - & - & \\
\hline & \multicolumn{8}{|c|}{ Element composition based on the dry mass of sewage sludge $m_{\text {element }} / m_{\mathrm{sS}, \mathrm{d}}$} \\
\hline$y_{c}$ & & 0.0737 & 0.1459 & 0.0252 & 0.0050 & 0.0019 & - & 0.2517 \\
\hline$y_{H}$ & & 0.0016 & 0.0288 & - & - & 0.0007 & 0.0106 & 0.0416 \\
\hline$y_{0}$ & & 0.0065 & 0.0875 & 0.0336 & 0.0133 & - & - & 0.1410 \\
\hline$y_{N}$ & & 0.0024 & 0.0196 & - & - & - & - & 0.0220 \\
\hline$y_{s}$ & & 0.0126 & 0.0100 & - & - & - & - & 0.0226 \\
\hline
\end{tabular}

Table 6: Calculated activation energies and correlation coefficient of the linear fitting as a function of $w_{\mathrm{RM}}$

\begin{tabular}{|c|c|c|c|c|}
\hline \multirow[b]{2}{*}{$w_{\mathrm{RM}}$} & \multicolumn{2}{|c|}{ FWO method } & \multicolumn{2}{|c|}{ KAS method } \\
\hline & $\mathrm{E}_{\mathrm{a}} / \mathrm{kJ} / \mathrm{mol}$ & $r^{2}$ & $\mathrm{E}_{\mathrm{a}} / \mathrm{kJ} / \mathrm{mol}$ & $r^{2}$ \\
\hline & \multicolumn{3}{|c|}{ Thermal decomposition of organic matter (zone I) } & \\
\hline 0.95 & 77.9 & 0.95 & 73.9 & 0.94 \\
\hline $0.90 \sim$ & 80.0 & 0.98 & 81.5 & 0.90 \\
\hline 0.85 & 122.11 & 0.94 & 119.4 & 0.94 \\
\hline 0.80 & 133.0 & 0.97 & 130.4 & 0.96 \\
\hline 0.75 & 148.7 & 0.97 & 146.7 & 0.97 \\
\hline 0.70 & 151.6 & 0.97 & 149.5 & 0.98 \\
\hline 0.65 & 136.1 & 0.99 & 133.0 & 0.99 \\
\hline 0.60 & 151.6 & 0.99 & 148.6 & 0.99 \\
\hline 0.55 & 145.4 & 0.99 & 142.3 & 0.99 \\
\hline 0.50 & 144.6 & 0.99 & 141.0 & 0.99 \\
\hline 0.45 & 143.8 & 0.99 & 139.8 & 0.99 \\
\hline 0.40 & 144.5 & 0.99 & 140.0 & 0.99 \\
\hline 0.35 & 153.6 & 0.99 & 149.3 & 0.99 \\
\hline 0.30 & 91.6 & 0.91 & 83.3 & 0.89 \\
\hline 0.28 & 71.7 & 0.85 & 61.6 & 0.79 \\
\hline \multicolumn{5}{|c|}{ Thermal decomposition of inorganic matter (zone II) } \\
\hline 0.25 & 91.9 & 0.75 & 81.7 & 0.68 \\
\hline 0.23 & 131.0 & 0.82 & 122.1 & 0.78 \\
\hline 0.20 & 166.3 & 0.95 & 158.8 & 0.94 \\
\hline
\end{tabular}




\begin{tabular}{lllll}
\hline 0.18 & 194.7 & 0.96 & 188.1 & 0.95 \\
\hline 0.15 & 183.2 & 0.93 & 175.6 & 0.91 \\
\hline 0.13 & 218.9 & 0.93 & 212.7 & 0.92 \\
\hline 0.10 & 278.2 & 0.96 & 274.7 & 0.95 \\
\hline 0.05 & 291.7 & 0.93 & 288.1 & 0.92 \\
\hline
\end{tabular}

\section{Nomenclature}

Symbol

A

$k_{0}$

E

$E_{\mathrm{a}}$

$M$

$m$

$n$

$T$

$t$

V

w

$x$

$y_{M}$

$\kappa$

\section{Subscript}

$\begin{array}{cc}\text { ad } & \text { As determined } \\ \text { ar } & \text { As received } \\ \text { cal } & \text { Calculated } \\ \text { d } & \text { Dry basis }\end{array}$

daf

$\exp$

$f$

G

i

inorg

L

Ol

Org

$\mathrm{p}$

RM

$S$

SS

$\mathrm{t}$

0
Ash content, wt\%

Pre-exponential factor, $1 / \mathrm{s}$

Energy, MJ

Activation energy, $\mathrm{kJ} / \mathrm{mol}$

Moisture, wt\%

Mass, $\mathrm{g}$

Reaction order

Temperature, ${ }^{\circ} \mathrm{C}$

Time, $s$

Volatile matter, wt\%

Mass fraction, wt\%

Stoichiometric coefficient, wt\%

Mass yield

Heating rate, $\mathrm{K} / \mathrm{min}$

Dry and ash free basis

Experimental

Final

Gas

Pseudo-component

Inorganic Liquid

Organic liquid Organic

Product

Reacting mass Solid

Sewage sludge

Theoretical

Initial

\section{Acknowledgements}

The authors gratefully acknowledge the financial support of the Department of Science, Technology and Innovation of Colombia - COLCIENCIAS (330-2011 and 80740-408-2019) and the Sistema General de Regalias - SGR (BPIN 2020000100469)

\section{References}

Álvarez J., Amutio M., López G., Barbarias I., Bilbao J. and Olazar M. (2015). Sewage sludge valorization by ash pyrolysis in a conical spouted bed reactor. Chemical Engineering Journal, 273, 173-183.

Anca-Couce A., Berger A. and Zobel N. (2014). How to determine consistent biomass pyrolysis kinetics in a parallel reaction scheme. Fuel, 123, 230-240.

Antal M., Varhegyi G. and Jakab E. (1998). Cellulose pyrolysis kinetics: Revisited. Industrial \& Engineering Chemistry Research, 37, 1267-1275.

Arenas C., Navarro M. and Martínez J. (2019). Pyrolysis kinetics of biomass wastes using isoconversional methods and the distributed activation energy model. Bioresource Technology, 288, 121485

Bergfeldt B., Morgano M.T., Leibold H., Richter F. and Stapf D. (2018). Recovery of phosphorous and other nutrients during pyrolysis of chicken manure, Agriculture, 8, 1-10.

Calvo L., Otero M., Jenkins B., García A.I. and Morán A. (2004). Heating process characteristics and kinetics of sewage sludge in different atmospheres. Thermochimica Acta, 409, 127135.

Casajus C., Abrego J., Marias F., Vaxelaire J., Sánchez J. and Gonzalo A. (2009). Product distribution and kinetic scheme for the fixed bed thermal decomposition of sewage sludge. Chemical Engineering Journal, 145, 412-419.

Chanaka W., Veksha A., Giannis A. and Lim T.-T. (2019a). Pyrolysis derived char from municipal and industrial sludge: Impact of organic decomposition and inorganic accumulation on the fuel characteristics of char. Waste Management, 83, 131-141.

Chanaka W., Veksha A., Giannis A., Lisak G. and Lim T. (2019b). Effects of sewage sludge organic and inorganic constituents on the properties of pyrolysis products, Energy Conversion and Management, 196, 1410-1419.

Cortés A. and Bridgwater A. (2015). Kinetic study of the pyrolysis of miscanthus and its acid hydrolysis residue by thermogravimetric analysis. Fuel Processing Technology, 138, 184-193.

Flynn J.H. (1997). The temperature integral its use and abuse. Thermochimica Acta, 300(1), 83-92.

Font R., Fullana A. and Conesa J. (2005). Kinetic models for the pyrolysis and combustion of two types of sewage sludge. Journal of Analytical and Applied Pyrolysis, 74, 429-438.

Furimsky E. and Sears P. (1988). Iron-catalyzed gasification of char in $\mathrm{CO}_{2}$. Energy \& Fuels, 2, 634-639.

Gao N., Kamran K., Quan C. and Williams P.T. (2020). Thermochemical conversion of sewage sludge: A critical review. Progress in Energy and Combustion Science, 79, 100843.

Gao N., Li J., Qi B., Li A., Duan Y. and Wang Z. (2014). Thermal analysis and products distribution of dried sewage sludge pyrolysis. Journal of Analytical and Applied Pyrolysis, 105, 43-48.

García A., Ariza J., Martín J., Díaz J.A.I. and Morán A. (2009). Kinetic models based in biomass components for the combustion and pyrolysis of sewage sludge and its compost. Journal of Analytical and Applied Pyrolysis, 86, 108-114.

Inguanzo M., Domínguez A., Menéndez J.A., Blanco C.G. and Pis J.J. (2002). On the pyrolysis of sewage sludge: the influence of pyrolysis conditions on solid, liquid and gas fractions. Journal of Analytical and Applied Pyrolysis, 63, 209-222.

Ji A., Zhang S., Lu X. and Liu Y. (2010). A new method for evaluating the sewage sludge pyrolysis kinetics. Waste Management, 30, 1225-1229.

Kacprzak M., Neczaj E., Fijalkowski K., Grobelak A., Grosser A., Worwag M., Rorat A., Brattebo H., Almas A. and Singh B. 
(2017). Sewage sludge disposal strategies for sustainable development, Environmental Research, 156, 39-46.

Karaca C., Sozen S., Orhon D. and Okutan H. (2018). High temperature pyrolysis of sewage sludge as a sustainable process for energy recovery. Waste Management, 78, 217226.

Karayildirim T., Yuksel M. and Bockhorn H. (2006). Characterisation of products from pyrolysis of waste sludges. Fuel, 85, 1498-1508.

Li C. and Suzuki K. (2010). Tar property, analysis, reforming mechanism and model for biomass gasification-an overview. Renewable \& Sustainable Energy Reviews, 13, 594-604.

Morf P., Hasler P. and Nussbaumer T. (2002). Mechanisms and kinetics of homogeneous secondary reactions of tar from continuous pyrolysis of wood chips. Fuel, 81, 843-853.

Neves D., Thunman H., Matos A., Tarelho L. and Gómez-Barea A. (2011). Characterization and prediction of biomass pyrolysis products. Progress in Energy and Combustion Science, 37, 611-630.

Nowicki L. and Ledakowicz S. (2014). Comprehensive characterization of thermal decomposition of sewage sludge by TG-MS. Journal of Analytical and Applied Pyrolysis, 110, 220-228.

Porada S. (2004). The reactions of formation of selected gas products during coal pyrolysis. Fuel, 83, 1191-1196.

Rincón S., Mendoza L. and Gómez A. (2019). Tratamiento térmico de biosólidos para aplicaciones energéticas, Kassel University Press, Kassel-Germany.

Roedder E. (1959). Silicate melt systems. Physics and Chemistry of the Earth, 3, 224-297.

Roskosch A. and Heidecke P. (2018). Sewage sludge disposal in the Federal Republic of Germany, Technical Report, German Environment Agency.

Sánchez M., Menéndez J., Domínguez A., Pis J., Martínez O., Calvo L. and Bernad P. (2009). Effect of pyrolysis temperature on the composition of the oils obtained from sewage sludge. Biomass and Bioenergy, 33, 933-940.

Seggiani M., Vitolo S., Puccini M. and Bellini A. (2012). Cogasification of sewage sludge in an updraft gasifier, Fuel, 93, 486-491.

Shao J., Yan R., Chen H., Yang H. and Lee D.H. (2010). Catalytic effect of metal oxides on pyrolysis of sewage sludge. Fuel Processing Technology, 91, 1113-1118.
Tang S., Zheng C. and Zhang Z. (2018). Effect of inherent minerals sewage sludge pyrolysis: Product characteristics, kinetics and thermodynamics. Waste Management, 80, 175185.

Thipkhunthod P., Meeyoo V. and Rangsunvigit P. (2007). Rirksomboom, Describing sewage sludge pyrolysis kinetics by a combination of biomass fractions decomposition. Journal of Analytical and Applied Pyrolysis, 79, 78-85.

Trinh T.N., Jensen P.A., Dam-Johansen K., Knudsen N.O. and Sorensen H.R. (2013). Influence of the pyrolysis temperature on the sewage sludge product distribution, bio-oil, and char properties, Energy \& Fuels, 27, 1419-1427.

Urban D. and Antal M. (1982). Study of the kinetics of sewage sludge pyrolysis using DSC and TGA. Fuel, 61, 799-806.

Urych B. and Smolinski A. (2016). Kinetics of sewage sludge pyrolysis and air gasification of its chars. Energy Fuels, 30, 4869-4878.

Van Soest P., Robertson J. and Lewis B. (1991). Methods for dietary fiber, neutral detergent fiber, and nonstarch polysaccharides in relation to animal nutrition. Journal of Dairy Science, 74, 3583-3597.

Varhegy G., Antal M., Jakab E. and Szabo P. (2007). Kinetic modeling of biomass pyrolysis. Fuel, 86, 1781-1788.

Wang L., Chang Y. and Li A. (2019). Hydrothermal carbonization for energy-efficient processing of sewage sludge: A review. Renewable and Sustainable Energy Reviews, 108, 423-440.

Wesenbeeck S.V., Prins W., Ronsse F. and Antal Jr. M.J. (2014). Sewage sludge carbonization for biochar applications. Fate of Heavy Metals, Energy \& Fuels, 28, 5312-5326.

Wichelns D., Drechsel P. and Qadir M. (2015). Wastewater: Economic asset in an urbanizing world, in: Dreschel P., Qadir M. and Wichelns D. (Eds.), Wastewater Economic Asset in an Urbanizing World, Springer, Dordrecht, pp. 3-14.

Xu Q., Tang S., Wang J. and Ko J. (2018). Pyrolysis kinetics of sewage sludge and its biochar characteristics. Process Safety and Environmental Protection, 115, 49-56.

Yang H., Yan R., Chen H., Ho Lee D. and Zheng C. (2007). Characteristics of hemicellulose, cellulose and lignin pyrolysis. Fuel, 86, 1781-1788.

Zhu X., Zhao L., Fu F., Yang Z., Li F., Yuan W., Zhou M., Fang W., Zhen G., Lu X. and Zhang X. (2019). Pyrolysis of pre-dried dewatered sewage sludge under different heating rates: Characteristics and kinetics study. Fuel, 255, 1-7. 